\title{
The Phenomenon of Aggression as a social problem
}

\author{
dr Norbert Pikuta \\ Wyższa Skoła Filozoficzno-Pedagogiczna Ignatianum, Kraków
}

In recent years there appear more and more voices, which claim, that the present civilization becomes the civilization of violence. There appear even many statements, that they are the result of the civilization, and especially lording in it omnipresent hurry as well as every-day competition.

Violence shows itself in many branches of life beginning right from the family environment, through quarrels of various sort of different societal groups, reaching international conflicts scale. It makes itself present in our schools, work places, various institutions, and unfortunately to a large degree in our families. It can be noticed in everyday interpersonal contacts, and it seems that it has replaced other forms of usual communication. Outbursts of anger and fury accompany more and more often not only at solving conflicts but also from futile reasons. Screams, shouts have replaced the talk. For many people it seems, that showing aggression will aid them in obtaining the purpose. Therefore, it is visible in all social circles not withstanding the social status, education or age etc. Outbursts of aggression accompany everyday talks between two people, and parliamentary disputes on the political scene. The violence carries with itself the fear, hatred, and also brings victims, as we can see it in the lastly strengthening terrorist attacks. The pictures of violence we can watch every day in adult movies and fairy tales for kids. The absolutely first place holds the action movie, where we view the most horrible scenes of fighting and murder, which cannot switch on our mood in an optimistic way. There spread cases of beating, heavy assault, hurting, which are a result of intended and planned actions. In this unpardonable way "are tackled" things in the world of business, in families, and more often among children. ${ }^{1}$ Aggression became a way for solving many things to release stress as well

\footnotetext{
${ }^{1}$ PETRO, M: Influence of television on moral development of childern and youth. In: Orbis communicationis socialis. Lublin : NORBERTINUM, 2007, s. 68.
} 
as to secure for oneself the best position in a given social group. It manifests, too, in the heaviest and the most numerous criminal assaults. These are kidnappings, rapes, murders with premeditation, bestial hurts, destroying of other peoples' belongings. It is most visible in the acting of the so called criminal world.

\section{The phenomenon of aggression}

In the literature of the subject many researchers deal with the problems connected with the manifestation of aggression and violence. Some treat them as synonyms, others as different behavior. These phenomena awake in recent times tremendous interest, and to a some degree fear. Commonly violence is understood as a "force" overpowering someone's power, physical advantage over somebody, be thrown lawlessly force, dominion, lawless deeds, done with the use of force: rape." ${ }^{2}$.The usual definitions of prevalence take into account three fundamental criteria: the kinds of behavior, the intentions and results of violence. It may have an instrumental character, therefore, constitute a means for realizing defined purposes or purposeless (searching contentment in cruelty over someone) individual or group.

Aggression and violence is the behavior by which a man hurts other people or themselves. The main source of such behavior is sustained earlier hurt, violence, or frustration connected with conflicts that a person is going through, psychological tensions or conscious troubles. ${ }^{3}$ The violence towards other people manifests most often through verbal aggression as well as moral, physical, psychological, and its exceptionally drastic form is the sexual violence ${ }^{4}$. In turn the violence regarding one's own self is expresses through physical wounding, psychological hatred, or suicidal tendencies"

Healt Organization, (WHO) demonstrates us the following definition of violence:

"Intentional use of physical force, jeopardizing or real, against oneself or someone else or against a group or society, what causes or is likely to cause wounding, physical damage, death, psychological pain, the distur-

\footnotetext{
${ }^{2}$ SKORUPKA, S. - AUDERSKA, H. - ŁEMPICKA, Z. (red.): Maty stownik jezyka polskiego. Warszawa : PWN, 1996, s. 651.

3 MICHANČOVÁ, S.: Sociálne a psychické dopady zamlčaného zločinu (s.68-77) In: MICHANČOVÁ, S. - PAVLOVÁ, L. (eds.) Rodina, konflikt a možnosti mediace. Křtiny: ESI, o.p.s., Evropský smírčí institut, 2011.

${ }^{4}$ MICHANČOVÁ, S.: Pastoral Reflections on Child Sexual Abuse. In: Human Development. Denver, Colorado : Vol 25, No 1, Spring 2004, s. 16-20.

5 DZIEWIECKI, M.: Agresja i przemoc. „Wychowawca”, 2/2007, p. 5.
} 


\section{DOI 10.2478/v10154-012-0004-y}

bance of development or depravation"6. Typology used in the World Report divides violence into three wide categories, depending, who is its addressee or originator:

- Violence directed at oneself (Auto-aggression): These is behavior of a suicide and self wounding. To suicide belong suicidal thoughts, the attempt to commit suicide, and suicide itself.

- Interpersonal Violence: It is a violence regarding a member of a family or a partner: most often takes place at family house with reference towards a child or wife and husband), or senior persons, and violence regarding person out of kin, often unknown: most often it happens away from home: here we have occasional acts of violence, rapes, or sexual violence toward others, violence in schools, work places, boarding houses for handicapped, youth acts of violence.

- Group violence: it depends on instrumental use of violence by people, who identify themselves as members of a certain group against other group with the aim to achieve economic, social or political profit. Here belong: Genocide, repressions and violations of human rights, terrorism organized crime, armed conflicts (interior states, among states).

The above typology takes into account also the nature of violence, and so divides violence as: Physical, psychical, sexual, depravation, and negligence ${ }^{7}$.

Despite the strengthening of this phenomenon the scientific understanding of violence did not become defined. In psychological literature we find above all the term aggression, which as an aim has to hurt. I. Pospiszyl. Acknowledges violence for "every non incidental acts, aiming at the personal freedom of a human being dignity, or adding to physical or physical harm of a person going much further to what is accepted by society rules in this respect" ${ }^{8}$. Violence is understood as causing an influence, forcing desired behavior. In the criminal branch the idea of violence is used often interchangeably with the notion of aggression in psychology. However, it is not true, because violence denotes only and only physical aggression, the most dangerous, the most harmful form of aggression".

\footnotetext{
${ }^{6}$ PIETRUSZKA, M.: Przemoc - wyzwanie dla świata. na podstawie: World Report on Violence and Health. World Health Organization, Geneva 2002.

${ }^{7}$ PIETRUSZKA, M.: Przemoc - wyzwanie dla świata. na podstawie: World Report on Violence and Health. World Health Organization, Geneva 2002.; PIKUŁA, N.: Przemoc $w$ rodzinie na tle uzależnienia alkoholowego w: Nauczyciel wobec problemów psychospołecznych ucznia. Kraków-Częstochowa 2009, p. 89.

8 POSPISZYL, I.: Przemoc $w$ rodzinie. Warszawa : [s.n.], 1994, p. 2.

9 BŁACHUT, J. - GABERLE, A. - KRAJEWSKI, K.: Kryminologia. Gdańsk : [s.n.], 2007, p. 265.
} 
Acts of violence, are an expression of growing in society an aggression, which in the opinion of psychologists is often an outcome of frustration or constitutes a form of behavior based on the earlier acquired patterns. The explanation of the very notion of the aggression will allow to understand the mechanisms aiding for making it visible, how violence works.

Among scientists dealing in social sciences, there is a dispute, if aggressive behavior comes out of human nature, is instinctive, or learned. This notion is the main problem of social psychology.

Various researchers of aggression, violence select a couple of aggressions. One of them is the theory of aggression as an instinct, which is the theory of Freud. According to this concept aggression is indispensable to survive, to maintain the species. He considered, that people out of nature are bestial and only imposed social order , and law norms force them to restrict their instinct of aggression and reshaping it into something else, useful social behavior. Others( For example Jan Jakub Rousseau) express the opinion, that people are benign out of nature and happy, whereas the aggression is provoked by society exerting destructive influence on people through imposing restrictions. Sociologists accept, that aggression is a habit of attacking and may be a lasting characteristic, characterizing the personality of a man. E.g. Buss thinks, that exist four factors determining the force of aggressiveness at an individual:

- First of them is the frequency and intensity of experienced frustrations and sorrow, attack, which come before the aggression. If a child, whose. Personality is just shaping, is being brought up in such conditions, they learn aggressive manners.

- The second factor deciding about the strength of aggressiveness at a given person is a kind of strengthend aggressive behavior. It may have a character of a reward of punishment, which shall be reached by an individual after "the blow out" in the form of beating or calling names.

- The third factor is the societal facilitation, which is to say the mutual influence of group members, causing the increase of behavior of a described sort.

- The fourth factor having an impact on aggressiveness of an individual is the temperament.

Bandura and Walters claim, that aggressive behavior leads to satisfying a defined need. As a result it leads to maintain the aggressive behavior, as a successful way of acting" ${ }^{10}$ Moreover, Dollard and his co-workers formulated in 1939, the rule, that aggression is the propulsion being a reaction

\footnotetext{
${ }^{10}$ KMIECIK - BARAN, K.: Młodzież i przemoc. Warszawa : [s.n.], 1999, p. 16.
} 
for frustration. A man in his life confronts various obstacles, and this causes, leading to emotional tension. The outcome of this is aggression. "In the opinion of Dollard the appearance of aggression and its strength depend on a couple of factors:

1. The appearance and strength of aggression depend on the degree of frustration.

2. The acts of aggression may be halted under the influence of punishment.

3. The acts of aggression may be transposed.

4. The acts of open aggression faster and more efficient, than the hidden aggression lessen the tension of frustration.

5. Aggressive behavior may have different directions, and not all situations of frustration lead to aggression" ${ }^{\prime 1}$.

Aggressive behavior may have as their foundation the instinct, however, the impact of a situation, or other societal factors, nay modify this behavior, or lessen it. The researchers of the problem turn their attention, that one has to differentiate between the enemy aggression, which is evoked by the feeling of anger, and its purpose is to cause pain or incur wounding, and instrumental aggression, which in itself is an act of aggression, but serves achieving quite other goal than causing pain or incurring wounding. Concise and very wide definition was used by R. A. Baron and D. R. Richardson, who, use the term of aggression for a description" of every form of human behavior, which as its aim has to harm or cause such hurts of other human being, motivated to avoid such treatment"12.

The violence is the state of frustration and has its source in the problems and interior struggles of a man, that is to say, it may be caused by sadness, sorrow, the feeling of depravation. The violence is one of commonly encountered states of frustrations. According to a psychologist Anna Sowińska' We call the frustration the changes, that take place in the acting of a man, under the influence of blocking his goals," as "straightforward effect of an obstacle appearance, that is stopping the passage of acts directed at realizing the purpose (fulfilling the need, solution of a task)"13. Whereas G. Meitzel writes, that, "we talk on frustration then when, a man tries to achieve some goal, but his endeavour directed at this goal is nullified or achieving this goal proves to be impossible"14.

On frustration as a cause of aggression writes also Tomaszewski. Aggression in his opinion may come into existence on the basis of frustration

\footnotetext{
${ }^{11}$ KMIECIK - BARAN, K.: Młodzież i przemoc. Warszawa : [s.n.], 1999, p. 17.

${ }^{12}$ BARON, R.A. - RICHARDSON, D.R.: Human aggression. New York : [s.n.], 1994., cyt. za: KRAHE, B.: Agresja. Gdańsk : [s.n.], 2005, p. 16.

${ }^{13}$ KMIECIK - BARAN, K.: Młodzież i przemoc. Warszawa : [s.n.], 1999, p. 16.

${ }^{14}$ MIETZEL, G.: Wprowadzenie do psychologii. Gdańsk : [s.n.], 2008, p. 43.
} 
of the need of dependence, the frustration of " affective needs", the frustration of wanting to achieve, the frustration of urges etc. ${ }^{15}$. Such factors, as restricted impossibilities of reaching a goal, not very strong pain impulses, evoke unconditional, emotional reaction of anger (fury, mad). The above mentioned author claims, that aggression is an often and in this meaning typical outcome of frustration, but not the only one of possible ${ }^{16}$. A strong meaning in the creation of frustration has also the so called relative depravation.

It is a feeling of an individual (or social group), that they possess less that they should or less that they might expect, or less that other individuals like them have. In the face of frustration a man may accept two different attitudes. The first of them will have a defensive character, whereas the other task character, that is to say, that frustration not only liberates in man strong, negative emotions, but also pushes them to acting.

The aggression steals into the social strata and may have various forms. E. Fromm names the following.

-"pseudo-aggression"- aggressive behavior, which may cause harm to someone, but do not have such intention,

-aggression by chance- aggressive acting, of which effect, but not the intention, is the harm incurred to other person,

- assertive aggression- going toward a goal, without useless hesitations, doubts or fears,

-defensive aggression - has as its aim to remove the jeopardy, the man is willing to act according to motivations programmed by his body proclivities directed at defensive aggression, when their life is jeopardized, health, freedom or property,

- conformist aggression- actions which are not a result of aggressive drives pushing the aggressor to destruction, but com from the exterior "orders", -instrumental aggression- which has as its aim to achieve what is necessary and desired"17.

Aggressive behavior may manifest themselves in different forms, e.g. physical aggression, verbal or expressive straightforward aggression or medial, most often verbal, accepting the form of felony lies, etc. These are vivid forms of open aggression. We can also point out to a spontaneous aggression "hot" and instrumental, "cold", undertaken with a premeditation $^{18}$. The extreme form of aggression is cruelty. It depends on physical or psychical destroying of a living human being in an especially violent

\footnotetext{
15 TOMASZEWSKI, T.: Psychologia. Warszawa : [s.n.], 1982, p. 780.

16 TOMASZEWSKI, T.: Psychologia. Warszawa : [s.n.], 1982, p. 644.

${ }^{17}$ FROMM, E.: Anatomia ludzkiej destrukcyjności. Poznań : [s.n.], 1998, p. 243.

${ }^{18}$ OBUCHOWSKA, I.: Agresja. w: Encyklopedia pedagogiczna. Warszawa : [s.n.], 1993, p. 7.
} 
way or sophisticated. Taking into account biological foundation of aggressive behavior, a search is being done in the factors conditioning them is the structure or physiology ${ }^{19}$. The research led among other things on the dependence between chromosomal structure and behavior disorders showed, that statistically there are more people with this anomaly in the criminal population. These type of disorders cause more often disturbances in the emotional sphere in individuals aggressiveness and imbalance. A research was also led on the neurological and physiological foundation of aggression, that is to say, searching for a certain structure in the brain or hormone responsible for it.

For the occurrence of aggression have also the impact the biologically-psychical processes. The control over aggressive behavior is held by at the same time at animals like humans the tonsilla body in the spinal cord. Its trembling stimulates aggressive behavior, whereas, in the moment of the body disappearance - the aggression goes away. The proclivity towards aggression evoked by the trembling of the body "tonsilla" may be modified by social factors (e.g. if we are in the company of someone weaker, lower placed in the social hierarchy $)^{20}$.

It appeared, that aggression might be the result of a play between certain structures in the brain. From the led experiments it may be concluded, that in the moment, when " the organism is stimulated for aggression we may observe a great deal of physiological changes- the activity of sympathetic system, hormone excretion, fast blood circulation, the breath becomes quicker and deeper" ${ }^{21}$. Among factors provoking aggression there are also named those connected with the hormone working and general bio-chemistry in the brain ${ }^{22}$. Persons with the low level of serotonin fall much easier and faster into the state of aggression. The level is dependent on the way one eats, but also stress ${ }^{23}$. A big influence on human aggression has testosterone. With women and men who committed crimes with the use of force, there is a higher level of this hormone than with the others. Hence we can conclude, that men are more aggressive than women, since their testosterone is at a higher level.

Another division of the definition was given by K. Kmieci-Baran in her conference on violence toward children. She names constructive aggres-

\footnotetext{
${ }^{19}$ HERMAN, J.L.: Przemoc. Uraz psychiczny i powrót do równowagi. Gdańsk : [s.n.], 1998, p. 11 .

${ }^{20}$ SOWIŃSKA, A.: Wprowadzenie do psychologii. Katowice : [s.n.], 2002, p. 26.

${ }^{21}$ GORĄCY, A.: Uwarunkowania zachowań agresywnych - przegląd badań. „OpiekaWychowanie-Terapia", nr 1-2, 1990.

${ }^{22}$ MICHANČOVÁ, S. Páchatel sexuálneho zneužívania detí medzi nami. Prešov : Prešovská univerzita, 2005, p.18.

${ }^{23}$ MASTALSKI, J.: Samotność globalna nastolatka. Kraków : [s.n.], 2007, p. 239.
} 
sion, that is to say, development, move forward, reaching for something. Constructive aggression might lead to criminality, these shall be actions opposing the existing at present laws and rights, but in accordance with the expectations of the society, e.g. saving one's family, through killing or wounding an offender. Other type of aggression, it is a destructive aggression, that is to say, violence, behavior aiming at the honor of a human being, not always having the criminal character, e.g. emotional violence, institutional etc. Destructive aggression is oftentimes a criminal reactionan action contrary to the existing norms of law, morality, customs, e.g. rapes, murder" ${ }^{24}$.

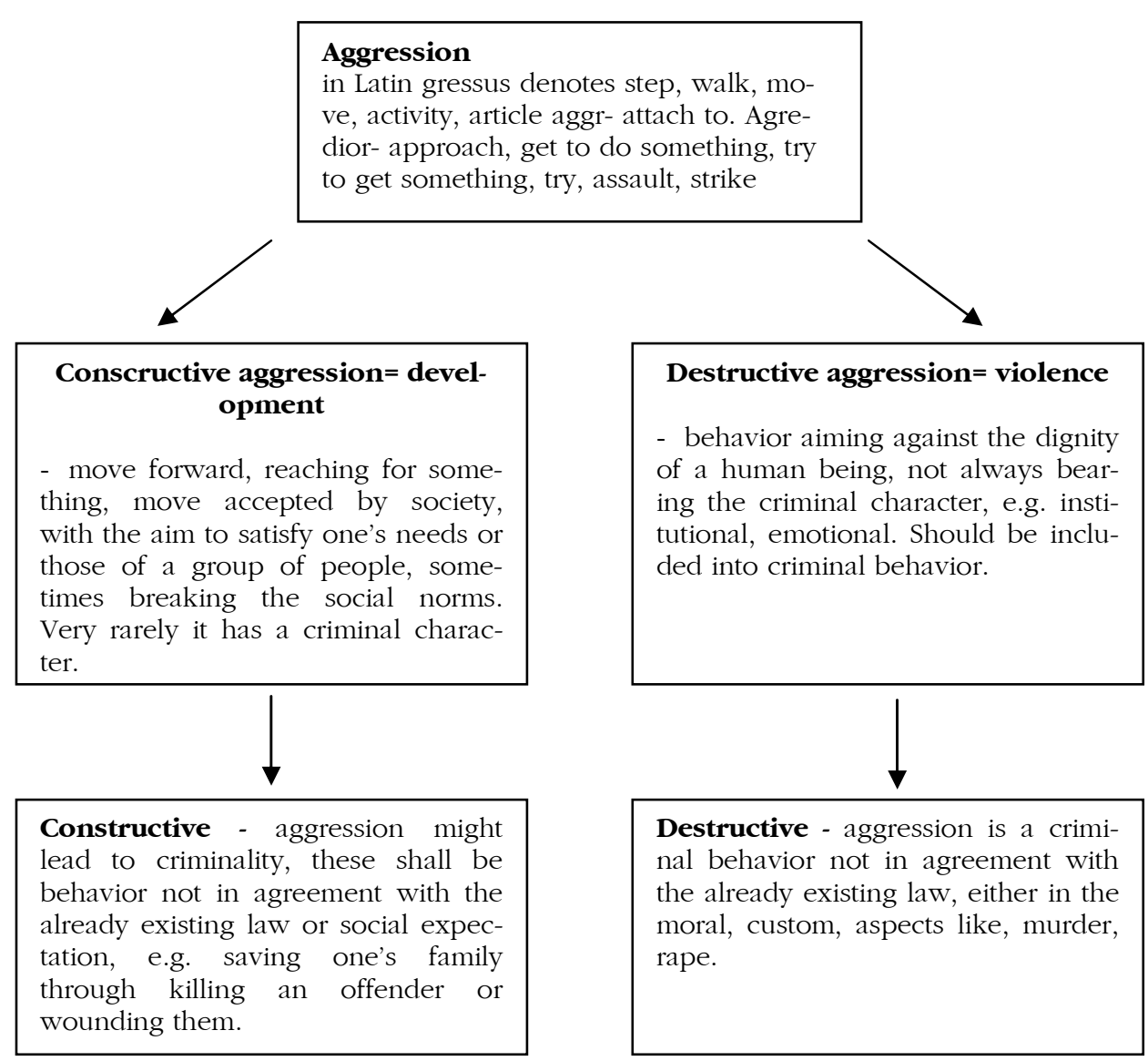

Picture 1. The notions of aggression, violence, criminality- their interrelation (according to K. Kmieć-Baran).

\footnotetext{
${ }^{24}$ KMIECIK - BARAN, K.: Młodzież i przemoc. Warszawa : [s.n.], 1999, p. 10.
} 
As I have mentioned earlier, aggression may be evoked also under the influence of various social situations. The theory of social studying preaches that, learning social behavior takes place through imitation and observation of other people. It is proved by scientific research, that children of parents, who used force toward their own kids, are likely to use it as well, thinking, that this is the right educative method. Also when we are confronted with aggressive behavior.

Which causes in us the desire of retaliation. The stimulus freeing out the aggression, may be a thing identified with aggressive actions of which the very presence makes the possibility bigger for attacks of violence to appear. The research shows, that access, e.g. to weapons in every-day use increases the number of committed crimes with its use.

In the literature of the subject an attention is being paid more often to the impact of aggression to be accessed in the mass media on the behavior of people. From many researchers led on this problem comes out clearly, that, the more in childhood a man watches brutal films, the more often as a teenager they behave in a violent way. Children after viewing aggressive scenes think, that they are given permission for making their aggression manifested freely. Watching the acts of violence in the media exerts also an influence on the adults, what causes, that seeing such situations in every-day life they become more and more indifferent and even accept them. It was also concluded that viewing hard porno scenes exerts very negative impact on the spectator. From the led research we see, that the marriage between the violence and sex leads to the acceptance of such behavior and this is an element responsible for aggressive behavior toward women. It had been also shown, that watching brutal sex, similarly violence in general, leads to benevolence with reference to such behavior, as well as showing less compassion to the victim of such treatment. The observation of people show, that, the more often they are exposed to brutality on the screens on the TV or in the cinema, causes the growth of tolerance for such behavior in real life. There arises a question, why? According to Aronson, it is above all, the permission - "if others may, do it, I may do it, too". Next, he, writes, that," watching aggressive actions might provide ideas, how to show one's own aggressive feelings", and "causes" that we better become aware of our anger and faster switch into move our aggressive actions" ${ }^{25}$.

The genesis of violence is also being sought in the troubling changes of family life, society, erotic customs, the relation among members of sexes and the crisis of common value. Next to the criminal violence we

\footnotetext{
${ }^{25}$ ARONSON, E. - WILSON, T. - AKERT, R.: Psychologia społeczna. Serce i umyst. Poznań : [s.n.], 1997, p. 513.
} 
have a wide-spreading common violence of every-day life. The violence is not always unanimous with a crime. There is also a behavior, which, despite the fact, that it does not violate the law, it stands against the universally accepted value norms, moral and custom. To them belong among other things: drug addiction, alcoholism which in turn may provoke criminal behavior. The most often committed under the influence of intoxicating means, like thefts, blackmail, burlglary. Much more immediate cause of a crime is an alcohol. In a differentiation from drugs, the alcohol is a domineering motivating factor for violent violence: fights, wounding, body hurts, attack at a functionary, and even murder. At the moment of intoxication, one stops fully control their behavior, and oftentimes become braver, does not observe norms or laws accepted. It is not to say that people after taking drugs or drinking alcohol become at once aggressive. This, if a man, will behave in $\mathrm{n}$ aggressive way, or not, depends on their psychical predisposition and from the strength of the social pressure at which they are exposed. Even weather conditions or climatic may have an influence on human behavior. To the most tragic abnormal behavior belong suicides and their attempts. The main cause of this behavior is school and family problems, as well as, unfortunate love. Rich explorative literature supports a connection between alcoholic stupor with men and aggressive behavior.

In recent times the general public is upset by the cases of using horrible violence also in families. The family for us is the closest and one of the most important environments, in which we live. We associate it with warmth, hospitality, and love. It constitutes an integral part of every society; it constitutes its smallest, and at the same time the fundamental unit. Is the most important social group, and for every man the basic group, that is to say, group, with which a man is very much grown with, a part of his personality, and important roles done out in society (the role of a husband, father, wife, mother, life-giver, etc.). The problem of violence in the family is almost always a taboo in the neighborhood where it prevails. From various reasons, persons experiencing the violence do not talk about it. The violence in the family, called also home violence it is an activity or its denial within family done by one of its members against other members of the family with the use of the power position and authority, hurting their rights or personal dignity, and especially at their life or health (physical or psychical) causing with them damage and suffering" ${ }^{26}$.

With reference to persons who experience violence in the family we can enumerate the following categories:

- the violence towards wife,

\footnotetext{
${ }^{26}$ MELIBRUDA, J.: Przemoc domowa. "Charaktery", nr 9, X, 1997, p. 14.
} 
- the violence towards husband,

- the violence toward senior persons,

- the violence toward children.

Various researchers of this phenomenon of violence are of the opinion, that, there is not one cause of doing damage to other people. There are many factors which make up for such a behavior, e.g.:

- the experience by parents during childhood the violence from their parents,

- the experience of emotional depravation during their childhood,

- the alcoholism of one or both parents,

- psychiatric disorders of parents,

- having children from different unions,

- maintenance factors (poverty, unemployment ${ }^{27}$.

Thanks to the educative-informative actions undertaken by the media and various organizations and institutions, the pathologies of family life stop being the taboo subject. All victims of family life, may speak about their drama and search help. Only, when the general public learns about the facts of violence, we can talk and undertake action to stop the violence.

In our country there exist many methods and procedures of psychological approach, e.g.:

- intervention methods,

- educative and counselling methods,

- emotional and social support,

- teaching of behavior,

- psychotherapy.

In Poland there also exist a great deal of various services and organizations dealing in helping the victims and those endangered by violence at home, but the cooperation among them is not yet brilliant. And the information that such services operate does not reach those in need in time, unfortunately. And these are:

$\checkmark$ Telephone of trust,

$\checkmark$ Police telephone of confidence,

$\checkmark$ Telephone "blue line",

$\checkmark$ Foundation Children of nobody,

$\checkmark$ The Committee of The Child's Rights,

${ }^{27}$ BADURA-MADEJ, W.: Wybrane Zagadnienia Interwencji Kryzysowej. Warszawa : BPS, 1996, p. 134; PIKUŁA, N.: Personalistyczne $i$ spoteczne skutki bezrobocia oraz troska o niepracujacych. w: Nauczyciel wobec problemów psychospołecznych ucznia. KrakówCzęstochowa 2009, p. 112. 
$\checkmark$ The Foundation for The Benefit Of the Protection Of Children Against Cruelty,

$\checkmark$ Police Children' Halls,

$\checkmark$ The centre of Crisis Intervention,

$\checkmark$ The state's Agency of Solving Alcohol Problems ${ }^{28}$.

The phenomenon of violence and aggression causes tremendous interest among researchers because of the weight of the problem and meaning of this most important social group. We may conclude, that the family becomes, the source of such behavior and their place, where aggression and violence find their outlet.

The reasons of the growth of the level of frustration, and by the same token aggression in Poland we may find as many as many branches of life we talk about.

The economic system and the pressure of life connected with the functioning in this system is the following factor favoring the excessive emission of frustration. The violence is visible not only in families, but also in the environment- in the life and activity of the society in the economy. In Poland the number of crimes bearing the economic character had increased from the time of transformation of the system many times. This fact is very damaging for the society, because among the poor strata of the people, there is a conviction that such atrocities are done by the richer members of the society. Because of that also we have a conviction of social inequality. Constant desire to amass material goods makes. That, Polish society becomes toward itself more indifferent and aggressive ${ }^{29}$. To fight the competition on the economic field they use all possible methods in this also violence. The permanent state of a race an human war, makes that we stop noticing troubling behavior of new generations. The effect of "falling out" of the so called "rats race" is often the loss of the will to live, showing itself by auto-aggression, or suicide. Life in our country is demanding, and difficulties we have to tackle, very often are beyond our possibilities.

Also, the poverty, unemployment, and the lack of perspectives for the betterment of the life situation favors the appearance of abnormal behavior. It deprives of the father's or mother's authority, degrades the family

\footnotetext{
${ }^{28}$ BADURA-MADEJ, W.: Wybrane Zagadnienia Interwencji Kryzysowej. Warszawa : BPS, 1996, p. 134; PIKUŁA, N.: Personalistyczne i społeczne skutki bezrobocia oraz troska o niepracujacych. w: Nauczyciel wobec problemów psychospołecznych ucznia. KrakówCzęstochowa 2009, p. 112.

${ }^{29}$ PIKUŁA, N.: Przemoc $w$ rodzinie na tle uzależnienia alkoholowego w: Nauczyciel wobec problemów psychospołecznych ucznia. Kraków-Częstochowa 2009, p. 97.
} 
socially $^{30}$. Maybe that is why we see more often coming into existence new subcultures based on the cult of strength and violence.

To end there comes a conclusion, that aggression and violence are almost every-day factors of behavior in society. It is a serious problem and causes doubts in the successfulness of undertaken actions with this phenomenon, on various fields of activity of man. The level of life of societies grows, education spreads. The civilization achievements and scientists discoveries had widened the horizons of man right to cosmos in the verbatim and figurative meaning, however, we cannot master the undesired behavior like violence and aggression.

\section{References}

ARONSON, E. - WILSON, T. - AKERT, R.: Psychologia spoteczna. Serce $i$ umyst. Poznań : [s.n.], 1997.

BADURA-MADEJ, W.: Wybrane Zagadnienia Interwencji Kryzysowej. Warszawa : BPS, 1996

BARON, R.A. - RICHARDSON, D.R.: Human aggression. New York : [s.n.], 1994.

BŁACHUT, J. - GABERLE, A. - KRAJEWSKI, K.: Kryminologia. Gdańsk : [s.n.], 2007.

DZIEWIECKI, M.: Agresja i przemoc. „Wychowawca”, 2/2007.

FROMM, E.: Anatomia ludzkiej destrukcyjności. Poznań : [s.n.], 1998.

GORĄCY, A.: Uwarunkowania zachowań agresywnych - przegląd badań. „Opieka-Wychowanie-Terapia", nr 1-2, 1990.

GRZYBEK, G.: Etyczne podstawy pracy socjalnej. Świadomość moralna, norma etyczna oraz wytyczne dla pracownika socjalnego $i$ pedagoga społecznego. Wyd. ATH. Bielsko-Biała 2007.

HERMAN, J.L.: Przemoc. Uraz psychiczny i powrót do równowagi. Gdańsk : [s.n.], 1998.

KMIECIK - BARAN, K.: Młodziė̇ i przemoc. Warszawa : [s.n.], 1999.

KRAHE, B.: Agresja. Gdańsk : [s.n.], 2005.

MASTALSKI, J.: Samotność globalna nastolatka. Kraków : [s.n.], 2007.

MELIBRUDA, J.: Przemoc domowa. "Charaktery", nr 9, X, 1997.

MIETZEL, G.: Wprowadzenie do psychologii. Gdańsk : [s.n.], 2008.

MICHANČOVÁ, S.: Páchatel sexuálnebo zneužívania detí medzi na$m i$. Prešov : Prešovská univerzita, 2005.

\footnotetext{
${ }^{30}$ Tenże, Personalistyczne $i$ społeczne skutki bezrobocia oraz troska o niepracujacych, w. Nauczyciel wobec..., as above, p. 110.
} 
MICHANČOVÁ, S.: Sociálne a psychické dopady zamlčaného zločinu (s.6877) In: MICHANČOVÁ, S. - PAVLOVÁ, L. (eds.) Rodina, konflikt a možnosti mediace. Křtiny: ESI, o.p.s., Evropský smírčí institut, 2011.

MICHANČOVÁ, S.: Pastoral Reflections on Child Sexual Abuse. In: Human Development. Denver, Colorado : Vol 25, No 1, Spring 2004, s. 16-20, ISSN 0197-3096.

OBUCHOWSKA, I.: Agresja. w: Encyklopedia pedagogiczna. Warszawa : [s.n.], 1993.

PETRO, M: Influence of television on moral development of childern and youth. In: Orbis communicationis socialis. Lublin : NORBERTINUM, 2007.

PIETRUSZKA, M.: Przemoc - wyzwanie dla świata. na podstawie: World Report on Violence and Health. World Health Organization, Geneva 2002.

PIKUŁA, N.: Personalistyczne i spoteczne skutki bezrobocia oraz troska o niepracujacych. w: Nauczyciel wobec problemów psychospołecznych ucznia. Kraków-Częstochowa 2009.

PIKUŁA, N.: Przemoc w rodzinie na tle uzależnienia alkoholowego w: Nauczyciel wobec problemów psychospołecznych ucznia. KrakówCzęstochowa 2009.

POSPISZYL, I.: Przemoc w rodzinie. Warszawa : [s.n.], 1994.

SOWIŃSKA, A.: Wprowadzenie do psychologii. Katowice : [s.n.], 2002.

SKORUPKA, S. - AUDERSKA, H. - ŁEMPICKA, Z. (red.): Maty stownik jezyka polskiego. Warszawa : PWN, 1996, s. 651.

TOMASZEWSKI, T.: Psychologia. Warszawa : [s.n.], 1982. 